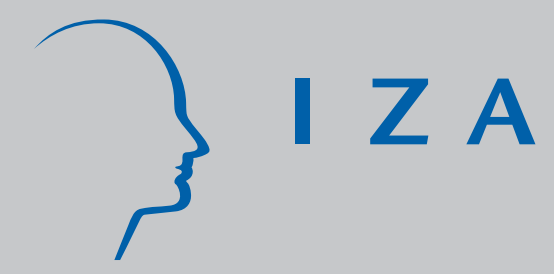

IZADP No. 3766

Understanding Low Average Returns to Education in Africa: The Role of Heterogeneity across Education Levels and the Importance of Political and Economic Reforms

Ruth Uwaifo Oyelere

October 2008 


\title{
Understanding Low Average Returns to Education in Africa: The Role of Heterogeneity across Education Levels and the Importance of Political and Economic Reforms
}

\author{
Ruth Uwaifo Oyelere \\ Georgia Institute of Technology \\ and IZA
}

Discussion Paper No. 3766

October 2008

\author{
IZA \\ P.O. Box 7240 \\ 53072 Bonn \\ Germany \\ Phone: +49-228-3894-0 \\ Fax: +49-228-3894-180 \\ E-mail: iza@iza.org
}

\begin{abstract}
Any opinions expressed here are those of the author(s) and not those of IZA. Research published in this series may include views on policy, but the institute itself takes no institutional policy positions.

The Institute for the Study of Labor (IZA) in Bonn is a local and virtual international research center and a place of communication between science, politics and business. IZA is an independent nonprofit organization supported by Deutsche Post World Net. The center is associated with the University of Bonn and offers a stimulating research environment through its international network, workshops and conferences, data service, project support, research visits and doctoral program. IZA engages in (i) original and internationally competitive research in all fields of labor economics, (ii) development of policy concepts, and (iii) dissemination of research results and concepts to the interested public.
\end{abstract}

IZA Discussion Papers often represent preliminary work and are circulated to encourage discussion. Citation of such a paper should account for its provisional character. A revised version may be available directly from the author. 
IZA Discussion Paper No. 3766

October 2008

\title{
ABSTRACT
}

\section{Understanding Low Average Returns to Education in Africa: The Role of Heterogeneity across Education Levels and the Importance of Political and Economic Reforms}

\begin{abstract}
Until very recently, the conventional wisdom was that the return to education was very high in Africa. However, some recent analysis point to low average returns to education in some African countries including Nigeria. Given these low returns to education, a relevant question is what causes low returns or what can cause changes in returns to education? In this paper, I examine the hypothesis that economic and political reforms can lead to increased returns to schooling using the case of Nigeria. Following the sudden death of military general Sanni Abacha, Nigeria moved to democracy in 1999, ending an over 15 years stretch of military rule. This move was followed by significant institutional and economic reforms, which provide an opportunity to examine the short term impact of reforms on returns to education. The average return to education is estimated using instrumental variables exploiting a quasi experiment in Nigeria. The results provide evidence that reforms implemented post democracy in Nigeria led to a $2.6 \%$ point increase in average returns to education. Furthermore, I find that the low average return to schooling in Nigeria reflects more the low returns at the primary and secondary levels.
\end{abstract}

JEL Classification: J08, O12, O15, P5

Keywords: returns to education, wage reform, military, democratic reform

Corresponding author:

Ruth Uwaifo Oyelere

School of Economics

Georgia Institute of Technology

781 Marietta Street

Atlanta, GA 30318

USA

E-mail: ruth.uwaifo@econ.gatech.edu 


\section{Introduction}

Until very recently, the conventional wisdom was that the return to education in developing countries, especially Sub Saharan Africa (SSA) is much higher than the rest of the world. This view is linked with the economic principle that the price of labor is higher if a skill is scarce and since educated labor is scarce in Africa, it follows that the returns to education must be high. In addition, this hypothesis of high returns has been backed by micro evidence by Psacharopoulos (1994) and several other authors who make use of ordinary least squares(OLS) to arrive at their findings 1 However, Card (1995), and Ashenfelter and Zimmerman (1997) have questioned the validity of many of these OLS estimates of the returns to schooling. They argue that OLS estimates of returns can be biased because of the endogenous nature of the schooling variable. Similarly, some instrumental variable (IV) estimates have also been question based on the validity of the instruments used for the analysis (see Staiger and Stock, 1997 and Card, 2001).

The possibility that returns to education for African countries could be less than previously estimated was highlighted both by Bennell (1996) and Glewwe (1991). They both argue that several of the earlier papers on Africa are flawed. Moreover, they state that Psacharopoulos' (1994) conclusion on African countries relies heavily on dated studies and unreliable data, and that a more careful Mincer type estimation of returns to education for similar countries reveals modest effects.

What are the key factors that are contributing to low returns to schooling in SSA? This is an important question in light of the expectation of high returns in SSA. I highlight three possible explanations for low returns to schooling in SSA. These three explanations are in no way exhaustive. The first reason is lack of physical capital and investments to complement skilled human capital. Poor school quality leading to minimal human capital accumulation and low returns to schooling is the second possible explanation. The third explanation for low return is labor market failures due to instability, bad policy choice, poor institution, and dysfunctional government. This is the argument I explore in this paper. Apart from these three explanations, low average return to education estimates might reflect the heterogeneity in returns to education across regions in a country and also disparities in returns to education at different levels of education. In this case, low returns to education in a region or at a level of education, that a good portion of the population belong to, may lead to a low average return even though high returns may exist in other regions or at other levels of education.

Labor market failures due to poor policy choice by a repressive government, political instability,

\footnotetext{
${ }^{1}$ see Psacharopoulos and Patrinos (2004) for a list of papers finding very high returns to education in Africa
} 
missing markets and poor institutions can all lead to low returns to schooling. Labor market failures in this context refers to a situation in which several factors including political regime and the actions and policy choices they make cause earnings not to reflect the market rate. Alternatively, labor market failures exit when wages do not reflect the marginal products of both skilled and unskilled workers. This potential explanation of low return to schooling is theoretically and empirically credible. Fleisher et al, (2005) noted the impact of reforms in the labor market on returns to education in many East European countries and Russia. The Nigerian case presents another opportunity to check for evidence for change in returns post significant reform. The sudden move to democracy and the concomitant institutional and economic reform furnish a natural experiment to test the validity of this explanation on why returns can be low and what can lead to an increase overtime. This is especially apt because there is documented evidence of serious political, economic and labor market problems during the repressive military rules in Nigeria (see Sanda et al, 1987) and evidence of substantial economic and institutional change post democratic reform.2

Towards this end, I seek to answer one question:

1. Did returns to education change significantly post 1999 (democracy) and can we attribute this change in returns if it exists to democratic reforms or does this change reflect other confounding factors that coincide with the post democracy period?

To answer this question I test three null hypotheses. First, there is no significant difference between returns to education pre and post democracy in Nigeria. Second, there is no differential change in returns to education across levels of education post democratic reform in Nigeria. Third, there is no differential change in returns to education across occupation sectors post democratic reform in Nigeria.

These three hypothesis along with other econometric analysis are the basis of identifying the effect of democratic reforms on returns to education. The results from this question can aid our understanding of what may have led to low returns to education in Nigeria and what factors can cause a change in this return.

The approach used to test the first hypothesis is to compare the Mincerian earnings function (Mincer, 1974) estimate of the average returns to schooling using instrumental variable (IV) prior and post economic reform and institutional change in Nigeria. As these changes and reforms came with the move to democracy, this analysis is equivalent to comparing returns in two different political

\footnotetext{
${ }^{2}$ See Okonjo-Iweala and Osafo-Kwaako, (2007) or Uwaifo (2008d)
} 
regimes in Nigeria. One regime is characterized by extractive institutions, labor market failures, poor policies and political instability (Military Rule) and the other regime (Democratic) characterized by political stability and large scale economic and institutional reforms. The instrument used is the length of exposure to a free education program in Nigeria. The variation in the instrument comes from exogenous withdrawal and implementation of the program across regions over time (see Osili and Long (2008) and Uwaifo (2007)). This first hypothesis alone is just a test of differences in labor market outcomes across two periods in time and does not on its own provide evidence of the effect of democratic reform as this difference could be due to trend effects or other confounding factors coinciding with either of the periods being compared.

Following the test of the first hypothesis, I next provide detailed arguments on why the pre and post comparison reflects changes due to democratic reform in Nigeria. I conduct different tests to show why this change is not driven by simple trend effects and confounding factors. In addition to these arguments, the second and third hypothesis are further tests that changes post 2000 can be linked to democratic reform. Given that many of the initial democratic reforms were aimed at certain groups in the population, I expect significantly bigger changes in returns to education across these groups in comparison to other groups. Specifically, I test for difference in returns to education across levels of education and across occupational sectors of the economy. Many of the reforms that can have short term benefits were geared towards those with higher levels of education and biased against those at lower levels of education. Hence, if changes post 2000 are linked to democratic reform, we should find unequal changes in returns to education across education levels with significantly higher increases for those with higher education in comparison to those at other levels. Similarly, one of the significant reforms post democracy was an increase in the minimum wage and a nonuniform wage reform implemented by the Federal Government. The wage increase was nonuniform with much larger increases to the senior more educated staff and smaller increases for the junior staff with lower levels of education. This wage reform led to a similar wage reform by the state government. Many big companies also had to raise wages for the educated to remain competitive and curb attrition to the government sector. Given this wage reform, one expects bigger changes in returns to education for wage workers than those who are self employed. More specifically if changes in returns is really due to democratic reform, we should see that government workers should have the biggest change in returns to education, followed by company workers. In contrast, those who are self employed should have the lowest change in returns to education if any.

It is important to mention that unlike the first hypothesis where the IV leads us to consistent 
estimates of the returns to schooling, the estimates of the returns at different levels of education have the potential to be biased because an IV strategy is not implemented. An IV strategy cannot be implemented in this case because suitable instruments for each level of education is lacking. I do not too worried about this issue because for in this paper I am concerned with a change in returns and not the absolute magnitude of the return to each level of education. As long as the bias in the estimates is not time variant, the identification strategy and the inferences based on this result should be valid. In my analysis, ability is the primary omitted variable which could bias the estimate of the returns to education at each level of education but ability should not be time variant in a birth cohort of a population. Besides, when I compare OLS and IV estimates of average returns to education, I do not find substantial bias in OLS estimates. This could imply that OLS estimate of the returns at different levels of education should not have substantial bias.

The results suggest that average returns to education differed significantly across the two political regimes. With a 2.6 percentage point increase post democracy. I provide econometric evidence suggesting that this difference is not due to simple trends, changing population or a confounding effect like the oil boom in Nigeria post 2003. Instead, the difference is due to democratic reform. With respect to the three hypothesis tested, I find that there are significant differences in the change in returns to education across levels of education. Specifically, the wage reform and policies directed towards skilled labor in Nigeria, along with the change in investment climate, all play a significant role in the 6.2 percentage point increase in the returns to tertiary education, post reforms which stands in contrast with the 0 percent increase at the secondary level and the 1.1 percentage point increase at the primary level. Also, there are significant differences across occupation sectors in the change in returns to education, wage workers experienced significantly higher increase in returns in comparison to those who were self-employed. Similarly, those who work for the government had a higher increase in returns than those who worked in the private formal sector and the informal sector. Specifically, returns increases by 2.4 percentage point for government workers while returns only increased by 0.8 percentage point for those in the private formal sector.

This paper contributes to the literature by providing some answers for important questions regarding low returns to education in Africa. The literature on schooling has not really emphasized the question of low returns to education because, prior to Uwaifo (2006), private average return to education in Africa was predicted to be high. However, identifying factors that can lead to low returns to education is not just informative for labor economists but can also serve as a guide to policy choices that deal with this problem and preventing future reoccurrence. In addition, the 
results suggest another possible explanation for low returns to education, poor government, policies and institutions. Also, the paper provides evidence of the short-term impact of reforms post a change in political institutions and regime on returns to schooling. There have been many theoretical papers on the impact of regime or institutional change on welfare. This paper would add to the limited literature providing empirical evidence of the impact of reforms on returns to education within a developing country.

The remainder of this paper is organized as follow: In the next section, I highlight some relevant literature and in Section 3 I give a brief history on Nigeria and provide arguments why regime change can affect returns. In Section 4, I describe the data I use and present descriptive analysis. In Section 5, the identification strategy, econometric analysis and results are highlighted. Implications, a summary of the results and policy recommendations are in the last section.

\section{Related Literature}

The positive cross-sectional correlation between schooling and labor market earning is one of the most studied and most stable economic relationships. However in the past, there was little in the literature that focused on low returns to schooling. This apparent dearth in the early literature might be linked with the fact that most estimates of returns to schooling have been moderate or high (generally above 6 percent for every extra year of schooling) 3

More recently, some authors have noted low returns to schooling, both in the developed and the developing world but only a subgroup of this authors have been able to explain the possible reason for the low or changing returns to education in these countries. Fleisher et al (2005) explore the pace of increase in return to schooling during the transition from planning to market economies over time and across several Central and Eastern European countries, Russia, and China. Their analysis makes use of metadata from 33 studies of ten transition economies covering a period from 1975 through 2002. Interestingly, they find that most of these transition economies had very low returns to education until the $90 \mathrm{~s}$. Estimated returns before reform were less than $5 \%$ in all countries except Hungary and Slovenia, which operated under considerably less rigid economic regimes than did most of the rest of Central and Eastern Europe and Russia (CEER). More importantly, they find that post-economic reform and change in institutions consistent with a move towards a market economy, returns to education rose significantly in these countries. Fleisher et al (2005) attribute low returns to education in these economies in the past to the planned schemes of wage compression and rigid

\footnotetext{
${ }^{3}$ High return to education has been noted in developing countries especially Africa.
} 
economic regimes and nonmarket prior to transition.

A similar paper by Gorodnichenko and Sabirianova (2005) investigates why returns to schooling in Russia and Ukraine diverged over the transition despite identical initial conditions and similar skill composition of employment. In 2002, the estimated return to schooling is two times less in Ukraine at $4.5 \%$ than in Russia at 9.2\%. They conclude, based on rigorous semi-parametric analysis, that this difference is due to price differences in both countries. They claim the price differences are likely linked with lower demand for educated labor, more limited labor mobility, higher separation costs, and the larger role played by trade unions in Ukraine. These factors are linked with the fact that Ukraine made very few structural reforms compared to Russia until 1997 and only after 1997 did the speed of reforms in Ukraine accelerate and the scope widen (Linn, 2001).

Low return to schooling was also noted in a Western Europe country. Fuenta and Jimeno (2005) looking at 14 member states of the European Union, construct estimates of the private return to an additional year of schooling for an individual of average attainment, taking into account the effects of education on wages and employment probabilities. Low return to education was noted in Sweden and this was attributed to the country's compressed wage structure. This wage structure is similar to the wage grid situation in most of East Europe and Russia before the transition reforms.

There are also other recent findings on low return to schooling in developing countries. Aranki (2005) and Daoud (2005) found extremely low returns to education in Palestine (between 2-3\%). Aranki's possible explanation for this low return was the Palestinian labor force dependency on Israeli jobs. As Palestinian jobs in Israel are predominantly low skilled, the Israeli demand for Palestinian labor may explain the low returns to schooling in Palestine. He also notes that many other factors are possible (see Angrist, 1995 and Daoud, 2005 for further discussion). In Pakistan, Mohammed (2006) notes low returns to schooling. In this study, he estimates returns to schooling for male income earners between the ages of 25 and 59 in Pakistan, using data from the Pakistan Integrated Household Survey. He finds a low return to an extra year of schooling. His suggested explanations are a macroeconomic environment that does not require high-skilled labor, or poor quality of schooling in Pakistan that does not equip students with the necessary skills to facilitate increased productivity and earnings. However, he calls for further investigation to pinpoint which of these factors is truly to blame for the low returns. In addition, Zhang et al (2005) note low returns of $2.7 \%$ in urban China using a within-twin-pair fixed effects model. Given the high previously noted estimates, Zhang et al suggest that much of the estimated returns to education in China, found in previous studies, are due to omitted ability or the family effect. 
With respect to Africa, which is traditionally expected to have the highest returns, Collier and Gunning (1997) note that there are no statistical findings that support the effect of education on increasing farm productivity in SSA. Glewwe (1996) also notes zero average returns to private wage workers in Ghana 4 In Uwaifo (2006), a quasi experiment in Nigeria is exploited and estimates of the return to education in this country using both the instrumental variable (IV) strategy and ordinary least squares (OLS) are derived. The results are surprising. The average return to education in Nigeria (a country that holds one fifth of the African population) is not higher than the return for countries in the developed world. In fact, the return to education is actually quite low for both private and public sector workers (about $2.7 \%$ for every extra year of schooling.). Her estimate is about nine percentage points lower than the previously estimated average return in Africa (Psacharopoulos and Patrinos, 2004 estimate that the return for SSA is about 12\%). She also notes significant time differences in returns to education 5 Her results in general are consistent with the observed stagnation and decline in school enrolment in several SSA countries in the 90s. She suggests that the rise in international migration in the 90 s and the move to rent seeking activities, may both point to individuals making rational responses to disappointing benefits or returns to education in many African countries 6 Apart from the above papers, there are other papers that find low and medium returns in Africa (see Uwaifo 2008c for a review on returns to education in Africa) but the lingering question is still why the low returns. Given the important potential implications of low returns to education, it is necessary to try to understand what can lead to low returns to education or what can cause returns to education to change significantly. I highlight a few of these reasons below.

The first possible reason for the low return mentioned above is the lack of complementary physical capital and investment for the human capital base in Nigeria 7 This argument implies that the return to schooling is low because there is little physical capital and technology to combine with human capital to generate output and increase income. Hence, most of the human capital, embodied in individuals, is dormant and unproductive and can lead to the low returns to education observed. This argument makes sense theoretically but is also not the explanation in Nigeria for several reasons. First in Uwaifo (2006), she finds time differences in returns to education in Nigeria. However, there is no systematic relationship between these time differences in returns to schooling

\footnotetext{
${ }^{4}$ Glewwe assumes the zero return to schooling could have been a result of measurement errors biasing estimates of returns towards zero, however, the positive returns for government workers in the same country, tends to contradict this argument.

${ }^{5}$ The return to education dropped by over $10 \%$ point from the 80 s to the $90 \mathrm{~s}$.

${ }^{6}$ See Akokpari (1998) and The International Organization for Migration (IOM) (1992), Report of the Conference on International Migration, Geneva for information on migration from Africa.

${ }^{7}$ This view is well documented in Adam's (2001) look at Tanzania.
} 
and measures/indicators of gross physical capital or technology 8 Moreover, those in industries and sectors with adequate physical capital and technology to complement their human capital had returns to education similar to others who lacked this complementary input. Hence, though capital and investments might have a role to play in driving increased returns to schooling, they do not for the most part explain the drastic fall in the returns to education in Nigeria in the $90 \mathrm{~s}$.

Low quality of education, though a common explanation for low returns, cannot also be an important explanation of this phenomenon in Nigeria for two reasons. First, Uwaifo (2006) notes that the return to education is not statistically different for different birth cohorts in Nigeria. Specifically, the older cohorts who, based on recent findings, are supposed to have gotten better education before the massive expansion in the $70 \mathrm{~s}$, also had returns to education equally as low as the later cohorts 9 Although different cohorts may have different education experiences in terms of quality over the last 50 years in Nigeria, all exhibit similar patterns of low returns to schooling. In addition, Uwaifo (2006) argues that low quality of education in Nigeria cannot be the main issue since individuals would not have been able to transfer their skills, from their education in Nigeria, to the developed world and get comparable jobs with much higher returns, if quality of education was very low (See Kollehlon and Eule, 2003). The transfer of skills from Nigeria to other countries, as occurred in the 90 s, suggests that quality of education could not have been that low though quality of education might be better in some other parts of the world 10

The view that the low return to education can mask marked geopolitical difference is plausible. Many regions could have really low returns and a few regions have high or average returns. Hence, the average return is low for the country as a whole. The potential of heterogeneity across regions within a country, biasing the average returns to education downwards, was investigated in Uwaifo (2008a) using a similar instrument as was used in Uwaifo (2007). The results show minimal geopolitical differences in returns to schooling in Nigeria even though other important economic differences exist across regions.

In addition, it is also possible that the low average return to schooling masks substantial heterogeneity in returns to education across levels of education. The argument here is that the relationship between years of schooling and income is nonlinear and increasing with the years of schooling. Hence, the return to an extra year of primary education is much less than the return to a year of secondary

\footnotetext{
${ }^{8}$ Examples of such indicators are, gross capital formation or gross investment.

${ }^{9}$ There is anecdotal evidence that the massive expansion in enrollment in the 70s was not matched with similar expansion in infrastructure and teachers which reduced the quality of education.

${ }^{10}$ We know based on the literature that improved quality of education can increase returns to schooling. However, in Nigeria the bigger problem seems to be within quality differences in contrast to general low quality of education.
} 
education and the return to an extra year of tertiary education is the highest. However, since education attainment in Nigeria is still low and most people have primary education or less, then the average return will be more of a reflection of the return to primary education. This opinion that the average return to schooling is low because of divergence returns across levels, with low returns at the primary level with greater population concentration and higher returns to secondary and tertiary education with fewer people, has support in the literature. Schultz (2004) finds that private returns in six African countries are highest today at the secondary and post secondary levels and low at the primary level. In Schultz's (2001) Ghana study, he observed this increasing pattern in returns to education. He reports estimates of return to schooling of about 4 percent, 10 percent and 16 percent for primary, secondary and post-secondary schooling respectively. His explanation is that serious bottleneck to education occurs at the secondary and post-secondary school level making demand for secondary and tertiary graduates much higher than supply of these graduates leading to high returns for this group (see Schultz, 1988). However, recent World Bank studies on youth unemployment in several SSA countries point to higher levels of unemployment among tertiary institution graduates (see World Bank, 2007). This finding questions the opinion that the demand for secondary and tertiary graduates is more than the supply. High levels of unemployment among those with higher levels of education, should not exist if labor supply is less than labor demand at these levels. Although Schultz's explanation for high returns at the secondary and tertiary level might not be appropriate for many countries in SSA, his view on returns is consistent with evidence from Ghana and Burkina Faso (see Glewee, 1991 and Kalzianaga, 2004). Aromolaran's (2004) results on Nigeria are partly different from Schultz findings. He finds a low return to both secondary and primary education and a high return to tertiary education.

There is also evidence of a totally opposite trend in returns to education across levels. In the past, the theoretical expectation was that the return to schooling falls as students extend their years of schooling into higher educational levels (Becker, 1964; Psacharopoulos and Woodhall, 1985). This expectation was backed by micro evidence by Psacharaopoulos and Woodhall (1985) who find returns are highest at primary level and decrease at secondary and postsecondary levels. The contradictory evidence above may point to differences across countries in the relationship between school attainment and income. However, it is hard to come up with any general conclusion on these differences because of the potential bias in the returns to schooling at different levels of education. Most estimates of returns to different levels of education in SSA are derived using OLS estimation of the wage equation. Hence, estimates can suffer from selectivity and omitted variables bias. 
Lastly, the view that institutions or governance can affect the returns to education ties indirectly with the political economy literature. For example, Acemoglu et al (2004) considers the relationship between democracy and education. The impact of changing government/institutions 11 on economic indicators has also been considered in the literature theoretically (see Acemoglu et al, 2001). Recently, there is an increased interest in case studies and empirical papers considering the impact of institutions/mode of government and change in institutions on economic indicators. Acemoglu and Robinson (2000), Acemoglu et al (2004), Rodrik and Rigobon (2004), Minier (1998) and Glaeser et al (2004) are other examples of papers considering this relationship. However, most of these papers consider the effect of a change in institution or government on income and inequality. Fleisher et al (2005) on the other hand is one of the few papers that tries to explain the impact of reforms, that come along with institutional change, on returns to schooling in a multi-country analysis.

\section{$3 \quad$ Nigeria Pre and Post democracy}

\subsection{A Brief History}

For most of her independent life, Nigeria has been controlled by the military government, which continued the extractive institutions established through colonial rule. The military government first took over in 1966 toppling the elected civilian regime in a coup d'etat. Several authors have written on the military government in Nigeria and its negative impact on every sector of the economy 12 Between 1986 and 1998, Nigeria experienced its worst political regimes since its independence. Political instability, pervasive corruption and poor military government with extractive institutions and weak policy choices were the hallmarks of this period. Besides, labor markets were stifled and wages were sometimes compressed and controlled by the military government. The last military regime is known to be the most oppressive, corrupt and divisive 13 This regime ended abruptly with the death of General Sanni Abacha on the 8th of June 1998.

The death of a person is usually a thing of sorrow, but not for many Nigerians who saw a ray of hope for the future with the demise of Abacha (from whose family has been recovered at least US\$770 million of stolen state cash) and the beginning of transition to democracy. The transition government lasted until May 1999. It was led by General Abdusalam Abubakar, a high-ranking commander in the late general's cabinet. It was a period of setting up the institutional and political

\footnotetext{
${ }^{11}$ North (1991) defines institutions as the rules of the game in a society or, more formally, are the humanly devised constraints that shape human interaction. He emphasizes that institution structure incentive in human exchange, whether political, social, or economic.

${ }^{12}$ Examples of authors on this subject are Dibie (2000), Nwagwu (2002)\& Sanda et al (1987).

${ }^{13}$ The low return to education in Nigeria documented in Uwaifo (2006) was observed over the period of this regime.
} 
framework for the shift to democracy. Also during this period, some drastic economic reforms were initiated. In May 1999, Olusegun Obasanjo became the president of Nigeria, ushering in the present democratic dispensation. The period between 1999 to present has been the longest stretch of democratic government in Nigeria 14

Four year after his first term, Obasanjo was reelected to serve another term 15 Lewis and Bratton (2000) noted from their survey of Nigeria that Nigerians are generally very positive about the move to democracy. Based on their study in January and February 2000, four out of five Nigerians expressed relative trust in the government, with nearly a third affirming they trust the president a lot. The political stability, and economic and labor market reforms in Nigeria after over ten years of instability and labor market failures are one of the obvious outcomes post democracy that might explain the trust in the government. In 2007 Nigeria swore in its next democratic president. This is the first time in Nigeria's history as a nation that it has had two consecutive civilian governments and is a sign of the changes in the political and institutional landscape of the country.

Though there were significant policy and institutional reforms post democracy, there are differences in opinion on the welfare impact of the shift. Generally, anecdotal and data evidence leans more in favor of positive welfare impacts. In Figure 1 for example, the kernel density of log income in 1998, 1999, 2000 and 2005 are presented. The rightward shift in density post democracy (2000 and 2005) is apparent. However, I do not focus on general welfare impacts of the shift to democracy in this paper. The question of interest is if labor market outcomes have changed post the reforms initiated from May, 1999. To answer this question I focus on estimating the change in returns to education post democratic reform in Nigeria.

\subsection{Why Low Returns to Education can be Explained by Political Regime and Policy Choices in Nigeria}

The return to education in Nigeria was low for most parts of the 90s during the military regime; in fact it was near zero for household heads in 1992 (see Uwaifo, 2006). However, this same study provides evidence of high returns for household heads in the mid 80s, (over 10\% for every extra year of schooling) 16 The natural question to ask is why the return to schooling dropped? During the military regimes between 1986 and 1998, Nigeria was politically and economically unstable. First, interference in the labor market by the military government led to a situation where wages of skilled

\footnotetext{
${ }^{14}$ The previous democratic government lasted four years between 1979-1983.

${ }^{15}$ The fact that the president won a re-election provides anecdotal evidence to his performance during his first term and the speed with which economic reforms occurred in Nigeria during this period.

${ }^{16}$ Interestingly the downward trend in returns to education coincides with the downward trend in political stability in Nigeria post 1985.
} 
Figure 1: Kernel Density of Log Income Pre and Post Democracy

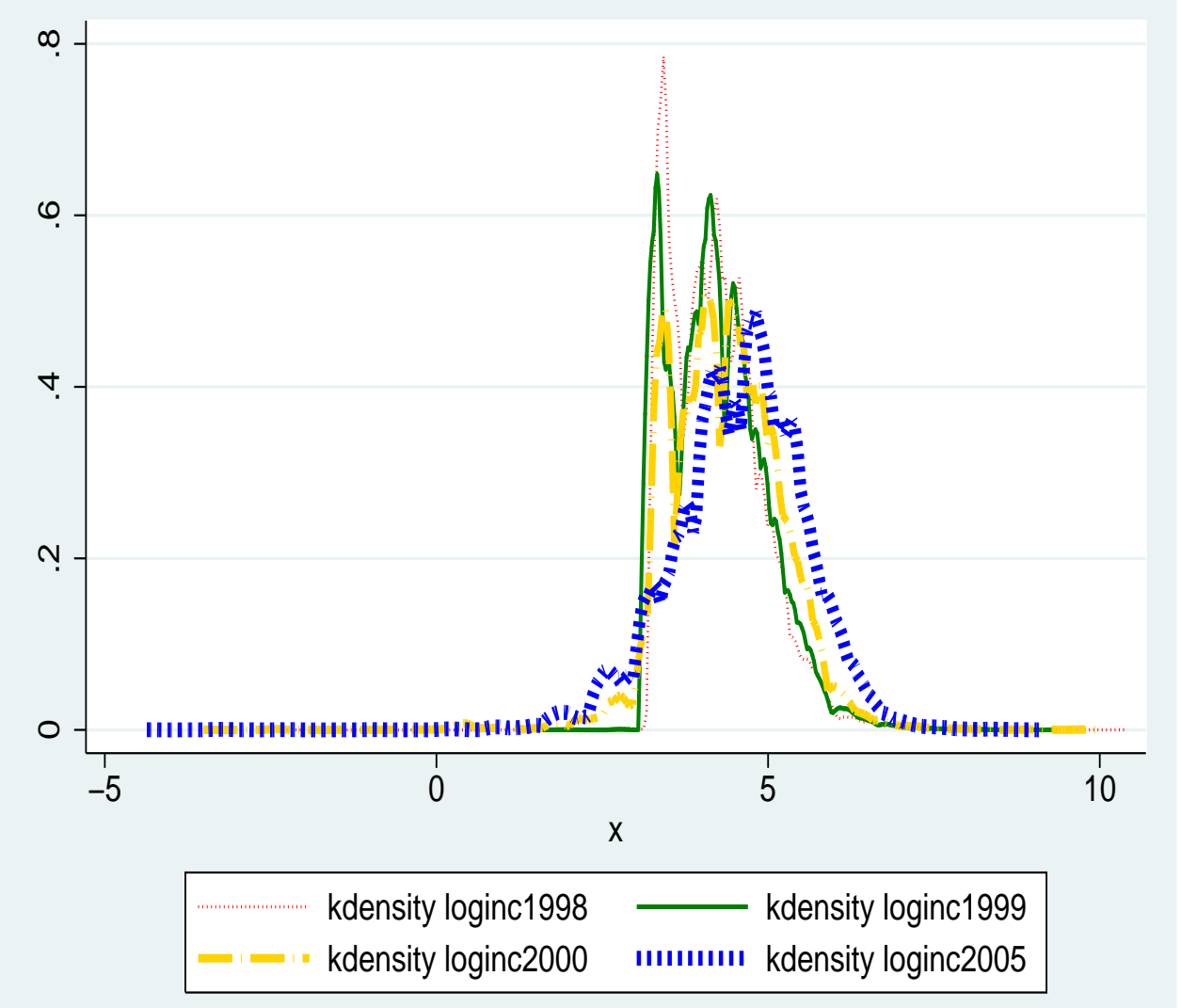

Note: 1998 and 1999 are pre democracy and 2000 and 2005 are post democracy.

and unskilled workers sometimes did not reflect relative marginal productivity. For example, this period in Nigeria was characterized by wage compression, underpaid workers and fixed wages in the large government sector though living costs were rising. Another market failure was job assignment based on social network. Most political positions and government contracts were assigned based on social network instead of qualification. In addition, institutions and legal-regulatory constraints, linked with military governance directly and indirectly created labor market instability, which further contributed to labor market failures. Lastly, political instability, weak policy choices, poorly defined property rights and inadequate enforcement of these rights by the military government stifled foreign and local investments. The direct effect of these investment constraints was reduced opportunities in the labor market that led to a labor supply-demand mismatch in some sectors. Excess supply of any kind of skilled labor can lead to low returns to education 17

\footnotetext{
${ }^{17}$ For more details on Nigeria under the military and the economic and institutional impact see Adejumobi (1995) and Soyinka (1997).
} 
One way to find out if low return to education can be explained by political regimes with poor policy choices is to compare Nigeria with and without the critical issues highlighted above. The move to democracy and the large-scale economic reform that followed provides an opportunity for such a comparison. This is possible for several reasons. First, the period following democracy has been characterized by major economic and labor market reforms. Several reforms were effected and regulation were put in place to ensure that political and non political appointments and government contracts are awarded only based on expertise and education unlike in the past when it was more arbitrary and linked mostly to social networks. Second, education was made a top priority in Nigeria post-democracy. In an attempt to salvage a sector so badly handled during the military years, the government encouraged school enrollment, through the UBE (Universal Basic Education), a program that makes school tuition free up to junior secondary school. The government also revamped the education testing boards at the higher levels of education to improve quality and transparency. Also, in an attempt to reward human capital and curb brain drain, the government significantly increased the wages of skilled capital in federal government services to more closely reflect their productivity. As noted in Uwaifo (2008b), another noticeable democratic reform was the over $100 \%$ increase in the Federal minimum wage for civil service workers in 2000. This was followed by increases in state minimum wage for civil service worker. Also a national minimum wage law was enacted that raises the national minimum wage dramatically from the monthly equivalent of 2.2 US dollars to fifty US dollars (250 to 5,500 Naira). In addition to this minimum wage increases, was a general nonuniform increase in wages across government employees, favoring more educated workers. The first minimum wage amendments did not satisfy the national labor union and was followed by subsequent minimum wage increases in 2001 18 As expected, these substantial wage increases had ripple effect in the private sector (see Folawewo (2007) for more on the impact of wage increases in Nigeria). Unlike in the military rule, civil service now became an attractive option for new graduates and workers already in the labor force. Hence, the wage rate in the private formal sector had to rise higher than in the public sector in some occupation categories to prevent a movement of higher ability/ skilled workers who typically were in the private sector to government service 19 As with any minimum wage policy, one would expect that there may be an effect on employment rates. Folawewo (2007) investigates this macroeconomic effect using a general equilibrium framework and his results are mixed. A possible reason why the wage increase had no consistent negative effect,

\footnotetext{
${ }^{18}$ The minimum wage in dollars per month for Federal and State Government workers in 2000 was approximately US $\$ 60$ US $\$ 50$ and increased by $15 \%$ in 2002 .

${ }^{19}$ An exception to most highly skilled workers being in the private sector are university professors who were all in the public sector as all universities were government owned until very recently.
} 
on employment across sectors, was the concurrent increase in demand for labor. This increase in demand for labor is linked to programs implemented post democratic reform that created new jobs and provided incentives for entry of many international and local firms.

Another big change in Nigeria post democratic reform is the business climate. This change further eased the school to work transition of many college graduates who typically before democracy, found it difficult to find jobs. Post 1999, several international firms returned to Nigeria and new international and local firms entered the market 20 These changes created an unprecedented increase in the demand for highly skilled labor. There was also an increase in the demand for unskilled workers as support staff like drivers, cooks, messengers for these new companies. This entry of new firms is due to the large-scale economic reforms, political stability and drastic change in the investment climate in Nigeria post democracy, in addition to the existence of a very skilled local labor force. A few examples of reforms post democracy include the privatization of some key public enterprizes, liberalization of key sectors of the economy, and restructuring of the public service. The phenomenal growth in the telecommunication sector and the substantial increase in demand for skilled labor in the private sector, are the most publicized examples on the impact of reforms on labor markets and the economy in post democratic Nigeria (see Okonjo-Iweala and Osafo-Kwaako, (2007) for a detailed analysis on reforms in Nigeria post democracy).

\section{Data and Descriptive Analysis}

\subsection{Data Description}

This study makes use of cross-sectional data from the General Household Survey (GHS) of Nigeria. The GHS is one of the major sample surveys carried out by the federal office of statistics (FOS). The survey sample was drawn randomly from all the 36 states in Nigeria including the federal capital territory. It is the only survey in Nigeria that resembles the Living Standards Measurement Survey (LSMS) of the World Bank in terms of coverage. For more information about the data see Uwaifo (2006). I make use of data from 1997/1998, 1998/1999, 1999/2000 and 2005 for answering both questions. The data contains information on 32,024 households in 1997/98 with 131,477 observations, 24,889 households in 1998/99 with 106,325 observations and 34,105 households in 1999/2000 with 149,411 observations, 28,268 households in 2005 with 97,689 observations. To ensure that the

\footnotetext{
${ }^{20} \mathrm{~A}$ classic example is the growth and expansion in the telecommunication sector triggered by the deregulation of the sector as part of the democratic reforms. The sector now consist of both local and international firms like Intercellular, Multi-links, Starcomms, G. S. Telecomm, Mobitel and Cellcom.
} 
Table 1: Summary Statistics

\begin{tabular}{ccccc}
\hline \hline Year & $\begin{array}{c}1997 / 98 \\
(\mathrm{GHS})\end{array}$ & $\begin{array}{c}1998 / 99 \\
(\mathrm{GHS})\end{array}$ & $\begin{array}{c}1999 / 2000 \\
(\mathrm{GHS})\end{array}$ & $\begin{array}{c}2005 \\
(\mathrm{GHS})\end{array}$ \\
\hline Observations & 131,477 & 106,325 & 149,411 & 97,689 \\
\hline Age & 23.486 & 23.32 & 23 & 22.98 \\
& $(18.049)$ & $(18.21)$ & $(18.26)$ & $(18.5)$ \\
Sex & 0.523 & 0.516 & 0.51 & 0.51 \\
(male=1) & $(0.499)$ & $(0.50)$ & $(0.50)$ & $(0.50)$ \\
Sector & 0.241 & 0.236 & 0.22 & 0.23 \\
(urban=1) & $(0.427)$ & $(0.425)$ & $(0.415)$ & $(0.418)$ \\
Years sch & 4.17 & 4.14 & 4.68 & 5.06 \\
& $(5.08)$ & $(5.136)$ & $(5.54)$ & $(5.61)$ \\
HH size & 6.12 & 6.337 & 6.42 & 5.58 \\
& $(3.34)$ & $(3.5)$ & $(3.49)$ & $(1.61)$ \\
Income & 92.672 & 93.73 & 114.72 & 136.4 \\
& $(298.298)$ & $(158.7)$ & $(305.82)$ & $(196.97)$ \\
\hline \hline
\end{tabular}

data are comparable over time, current monetary values had to be deflated to base year prices 21 Table 1 shows summary statistics for each year I consider in this analysis.

Table 2: Real Mean Household Income Pre and Post Democracy

\begin{tabular}{|c|c|c|c|c|}
\hline Zones & 1998 & 1999 & 2000 & 2005 \\
\hline & \multicolumn{2}{|c|}{ Pre Democracy } & \multicolumn{2}{|c|}{ Post Democracy } \\
\hline & Mean(SE) & Mean(SE) & Mean(SE) & Mean(SE) \\
\hline No Education & $\begin{array}{l}79.28 \\
(2.20)\end{array}$ & $\begin{array}{l}76.91 \\
(1.30)\end{array}$ & $\begin{array}{l}87.12 \\
(1.82)\end{array}$ & $\begin{array}{c}104.98 \\
(1.46)\end{array}$ \\
\hline Some Primary & $\begin{array}{c}113.26 \\
(18.63)\end{array}$ & $\begin{array}{l}91.24 \\
(3.17)\end{array}$ & $\begin{array}{c}106.79 \\
(4.45)\end{array}$ & $\begin{array}{c}108.06 \\
(4.17)\end{array}$ \\
\hline Full Primary & $\begin{array}{l}94.38 \\
(1.42)\end{array}$ & $\begin{array}{l}97.97 \\
(1.73)\end{array}$ & $\begin{array}{c}117.78 \\
(3.13)\end{array}$ & $\begin{array}{l}120.7 \\
(2.11)\end{array}$ \\
\hline Full Secondary & $\begin{array}{c}113.82 \\
(2.07)\end{array}$ & $\begin{array}{l}120.98 \\
(2.24)\end{array}$ & $\begin{array}{c}119.96 \\
(3.44)\end{array}$ & $\begin{array}{l}163.20 \\
(2.82)\end{array}$ \\
\hline Tertiary & $\begin{array}{c}155.16 \\
(3.98)\end{array}$ & $\begin{array}{c}178.14 \\
(5.3)\end{array}$ & $\begin{array}{c}198.34 \\
(5.2)\end{array}$ & $\begin{array}{c}298.36 \\
(5.8)\end{array}$ \\
\hline
\end{tabular}

\subsection{Descriptive Evidence for Increase in Returns to Schooling}

In Table 1, summary statistics are presented for Nigeria pre and post democracy. These statistics provide evidence for the similarities pre and post democratic reform in basic demographic character-

\footnotetext{
${ }^{21}$ The base year is 1985 .
} 
istics. In addition, the similarities across years make comparisons between time periods reasonable. The results show that years of schooling have increased by almost a year post democracy. This increase is expected though notable given the efforts made to emphasize education post democracy. Table 1 also provides clear evidence that general welfare has increased post democracy. Mean income, an indicator of welfare has risen by about 40 Naira in real terms. This is substantial as in current Naira this would be an increase in mean income of over 5800 Naira. Figure 1 also highlighted this shift in mean income post democracy. Though this improvement in welfare is important, this paper is focused on changes in benefits/returns to education post democracy.

Figure 2: Fitted Values of Income vs Schooling (Pre and Post democracy)

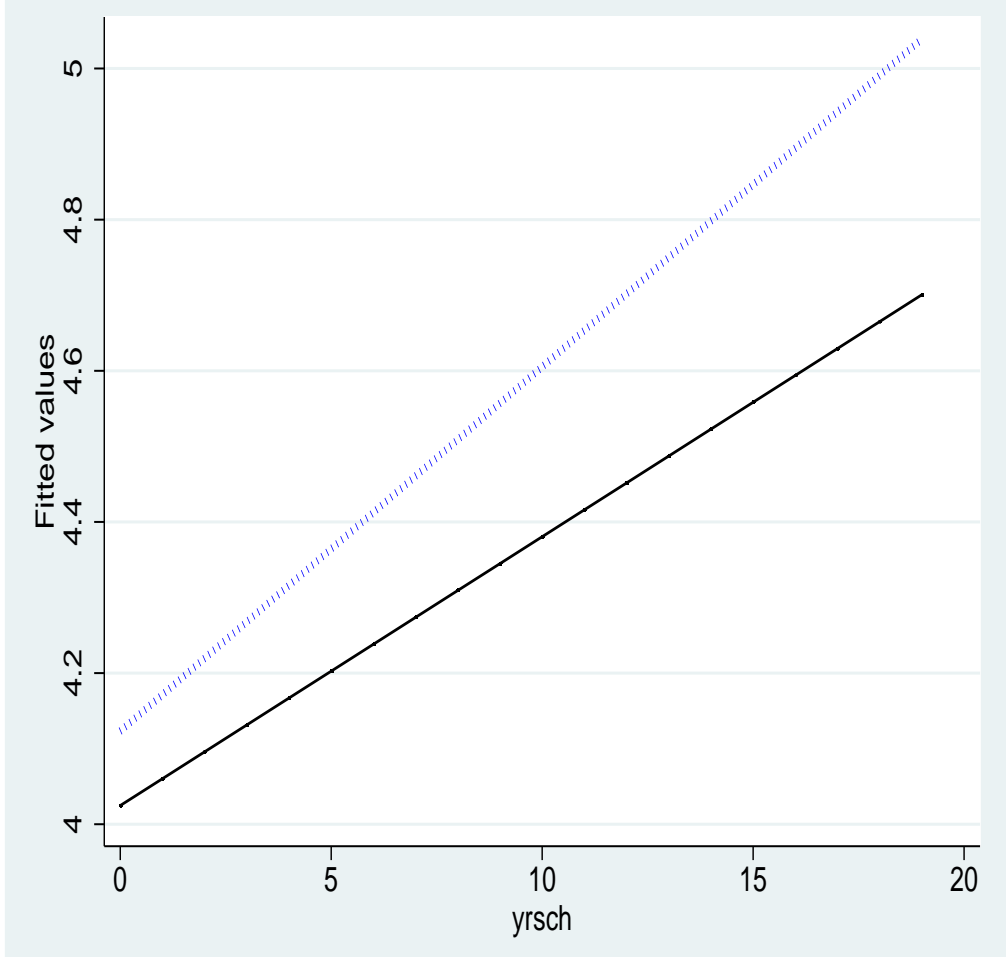

Note: Dotted blue line is fitted values post democracy (top plot) and black solid line is pre democracy (bottom plot).

There are several ways to check for descriptive evidence of possible change in returns to education post democracy. Figure 2 is a graph of the fitted values of log income in a regression of income on schooling pre and post democracy. Though this is a simple linear prediction with no controls, this figure provides some evidence of a level shift in income at all levels of school attainment post democratic reform. In addition, the slope of the line has increased which may point to an increase in returns to education post democracy. In Table 2, the mean income at each level of education for 
the four years being considered is summarized. In Table 3, the summary of mean income combining data separately, pre and post democracy at different levels of education is presented. First, Table 2 shows that mean income did not only increase post democracy (2000 and 2005) but also increased progressively with education level. Table 3 column 4 highlights change in income at each education level post democracy. This change increases with education level and is suggestive evidence of increase return to education post democracy. Both tables show that people with tertiary education benefited the most in terms of changes to mean income post democracy. For example, the difference in means income pre and post democracy for those with tertiary education is twice the difference for those with full primary education or less. Hence, a non-linear increase in income by education level post democracy is evident.

Figure 3: Median Spline of Income vs Schooling (Pre and Post democracy)

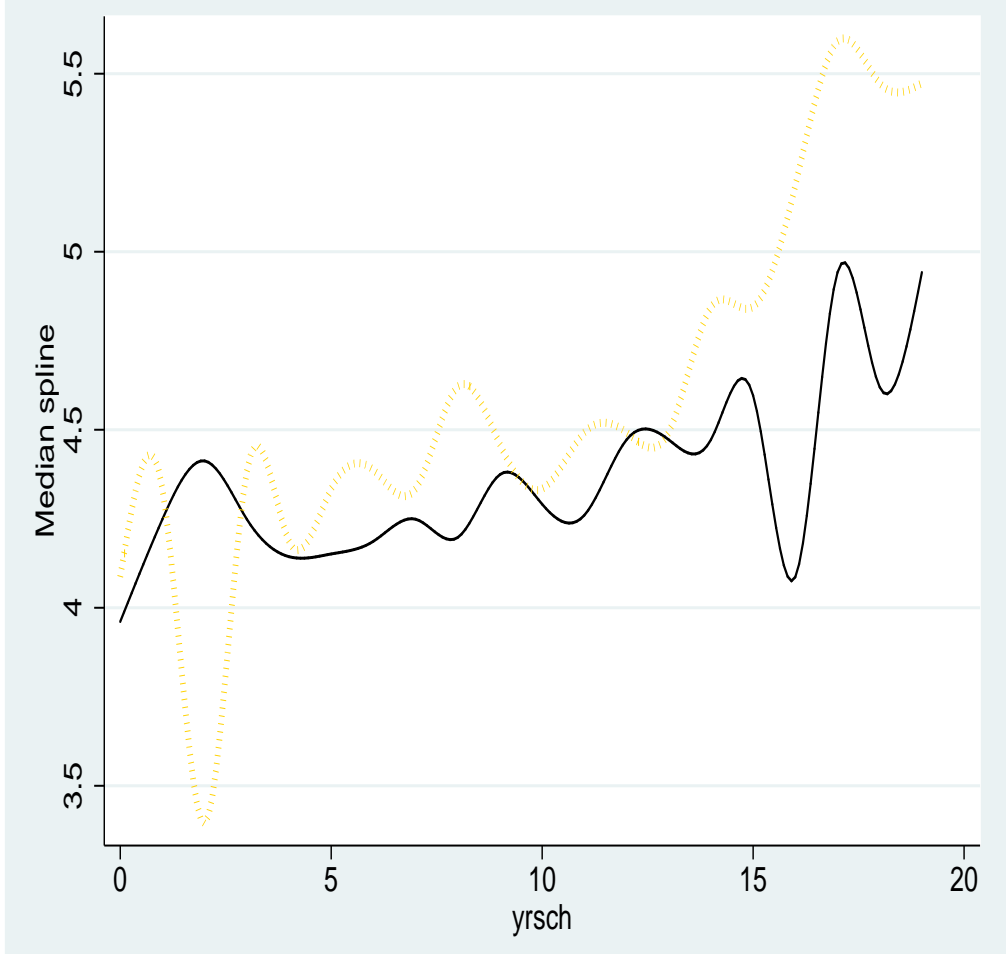

Note: Dotted gold line is median spline post democracy (higher plot) and black solid line is median spline pre democracy (lower plot).

To provide more evidence of this nonlinear increase post democracy, a graph of the median spline income on years of schooling pre and post democracy is presented (see Figure 3). In this figure, nonlinearities in returns to schooling is evident at the tertiary level of education. These nonlinearities became more pronounced post democracy. The difference between the pre and post 
democracy graphs is obvious at the tertiary levels. In contrast, the difference between both periods is small at at the primary -mid secondary level. The above descriptive evidence is strongly in support of not just positive welfare changes after 1999, but also positive changes in terms of returns to education. However, all the above evidence needs to be confirmed with rigorous econometric analysis before one can make a concrete inference and statement on if returns to education changed post democracy, and if this change is simply a trend effect, captures secondary confounding factors or can be linked with democratic reform.

Table 3: Real Mean Household Income Pre and Post democracy

\begin{tabular}{cccc}
\hline \hline Zones & Pre democracy(pooled) & Post democracy(pooled) & Difference \\
\cline { 2 - 4 } & Mean(SE) & Mean(SE) & \\
\hline No Education & 78.24 & 93.81 & 15.57 \\
& $(1.36)$ & $(1.27)$ & \\
Some Primary & 103.02 & 107.21 & 4.19 \\
& $(10.07)$ & $(3.29)$ & \\
Full Primary & 95.92 & 119.0 & 23.08 \\
& $(1.1)$ & $(2.03)$ & \\
Full Secondary & 117.02 & 151.55 & 34.53 \\
& $(1.52)$ & $(2.27)$ & \\
Tertiary & 165.98 & 225.7 & 59.72 \\
& $(3.28)$ & $(4.12)$ & \\
\hline \hline
\end{tabular}

\section{Descriptive and Econometric Analysis and Results}

\subsection{Estimation Strategy to Test Hypothesis 1}

As earlier stated, I focus on one broad questions in this paper. Did returns to education change significantly post 1999 (democracy) and can we attribute this change in returns if it exists to political and labor market reforms or does this change reflect other confounding factors that coincide with the post democracy period?

Given the nature of the question, I approach answering this question in three steps.

First I provide evidence that their is a significant change in returns to education between the two periods considered.

Step 2: Second I provide arguments both econometric and descriptive why this change is driven by democratic reform in Nigeria and not other potential confounding factors.

Step 3: Third, I test three hypothesis that capture differential changes in returns to education post democracy. This part of the analysis provides concrete evidence that the changes in returns to education post democracy are linked with specific policies as part of the democratic reform. 


\section{Step 1: Estimation and Results}

I make use of IV analysis to derive consistent estimates of the returns to schooling. First as a benchmark, the average return to schooling is estimated using OLS on a simple Mincer type earnings function (equation 1), pre and post democracy. Meaning the return to education is estimated pooling together data pre democracy then pooling together the post democracy data.

The average return to schooling estimated using OLS on equation (1), potentially suffers from endogeniety and omitted variable bias. Hence, the return to schooling is re-estimated pre and post democracy using an instrumental variable in a two stage least squares estimation of the equations below (equations 1 and 2). The assumption here is that schooling $S_{i}$ is a function of several variables including the instrument $Z_{i}$. In all the estimations, potential heteroscedasticity is corrected for and standard errors are clustered by birth cohort and state. In this analysis I focus on the cohorts born before 1982. I explain the rationale for this restriction in section 5.4.

$$
\begin{gathered}
{ }^{\natural} \log \left(y_{i}\right)=\alpha+\beta_{1} S_{i}+\beta_{2} X_{i}+\beta_{2} X^{2}+\beta_{3} D_{i}+\epsilon_{i} \\
S_{i}=\lambda_{0}+\lambda_{1} Z_{i}+\lambda_{2} P_{i}+v_{i}
\end{gathered}
$$

Here $X_{i}$ is age of individual $i, S_{i}$ is years of schooling of individual, $D_{i}$ is a vector of all other possible exogenous/control variables including dummies for individual $i, Z_{i}$ is the instrumental variable while $P_{i}$ is a vector which contains all other explanatory variables affecting schooling, $\epsilon_{i}$ and $v_{i}$ are uncorrelated error terms, $\alpha$ and $\lambda_{0}$ are the intercept term and $\beta_{1}$ is the estimate of the return to education/schooling. Using OLS the estimate of $\beta_{1}$ could be biased but with the IV strategy, this estimate should be consistent. The need for regional controls in the wage equation analysis was highlighted in Uwaifo (2007). The control variables we use in the regressions are age, sector, sex and states. The estimates of the return to schooling pre and post democracy are then

compared for statistical difference. If $\beta_{1 \text { pre }}=\beta_{1 \text { post }}$ then I fail to reject the null hypothesis but if otherwise the null hypothesis is rejected.

\section{The Instrument for Schooling}

As mentioned earlier, the empirical strategy for estimating $\beta_{1}$ requires an instrument. The instrument used in this analysis is the length of exposure to the free education program in Nigeria. The idea for an instrument linked with the exposure to free education came originally from the work of 
Osili and Long (2008), on the impact of education on fertility in Nigeria. I construct the instrument in this paper in line with Uwaifo (2006).

The instrument is based on the length of time exposed to a free primary education program with different periods of implementation across states/regions. The program was designed to increase educational attainment 22 The length and timing of exposure is based on program history as documented in the papers mentioned above and other historical facts on the program and education expansion in Nigeria (see Fafunwa, 1974, Ozigi\& Ocho, 1981 and Mazonde, 1995). The program was initiated during colonial and military rule in Nigeria which is a good argument against the view that implementation of the program was not exogenous and reflects individuals preferences.

A key factor that makes this a good instrument and creates variation in exposure is the exogenous implementation and withdrawal of the free education program across regions. Meaning different birth cohorts in different regions and states were exposed to free education for different lengths of time. This information is then used to construct an instrument to predict schooling. The UPE instrument satisfies the necessary characteristics of any good instrument because it is not only relevant but also exogenous and satisfies exclusion restrictions 23 Details on the program, its relevance and timeline are well documented in Osilli and Long (2008), Uwaifo (2006), Nwanchukwu (1981) and Chuta (1986).

Table 4: Estimates of IV impact(1st Stage)

\begin{tabular}{|c|c|c|c|c|c|}
\hline \multirow[t]{2}{*}{ Independent Variable } & & & & & \\
\hline & Regime & OLS & IV & $R^{2}$ & $\bar{F}$ \\
\hline UPE & Military & NA & $\begin{array}{c}0.17^{*} \\
(0.009)\end{array}$ & 0.36 & 1524.11 \\
\hline UPE & Democracy & NA & $\begin{array}{l}0.14^{*} \\
(0.01)\end{array}$ & 0.33 & 1319.94 \\
\hline
\end{tabular}

Note: $* 5 \%$ significance level

\subsection{Econometric Results}

In Table 4, the first stage regression estimates of the impact of the instrument on schooling are presented. The impact of the UPE program pre democracy is similar to the estimates in Uwaifo

\footnotetext{
${ }^{22}$ The nation-wide version of this program was launched in 1976 and called Universal primary education (UPE).

${ }^{23}$ In Uwaifo (2007), arguments and rigorous analysis to support the validity of the instruments along these criteria are provided to buttress the point that estimates of returns to education using this instrument are consistent.
} 
Table 5: Estimates of Returns to Schooling (2nd Stage)

\begin{tabular}{cccccc}
\hline \hline Independent Variable & \multicolumn{6}{c}{} \\
\cline { 2 - 6 } & Regime & OLS & IV & IV $R^{2}$ & $\mathrm{~F}$ \\
\hline \multirow{2}{*}{ Yrs of School } & Military & $0.026^{*}$ & $0.031^{*}$ & 0.23 & 303.5 \\
& & $(0.001)$ & $(0.001)$ & & \\
Yrs of School & \multirow{2}{*}{ Democracy } & $0.041^{*}$ & $0.057^{*}$ & 0.26 & 384.83 \\
& & $(0.001)$ & $(0.012)$ & & \\
\hline \hline
\end{tabular}

Note: $* 5 \%$ significance level

(2007). For the years post democracy, the impact is slightly smaller but is still substantial and significant. Table 5 captures the return to schooling estimates. The OLS estimates are also presented as a benchmark. First, the IV estimates are larger than the OLS estimates in both cases. Such a finding is not new in the literature and in Uwaifo (2007) this trend is noted when trying to estimate the average returns to schooling between 1997-1999. Several reasons have been postulated for this difference. Angrist and Krueger (1991) and Card (2001) demonstrate that OLS estimates are typically lower than IV estimates as the downward bias resulting from measurement error is often bigger than the upward bias due to omitted variables such as ability. This is especially relevant in developing countries where we expect more measurement errors in variables such as school attainment.

Anther possible reason for the IV estimates being higher is heterogeneity at the individual level in returns to schooling. Here, the IV estimates will be upward biased. This difference between OLS and IV estimates is not a major issue for these results. Similar to Uwaifo (2007), OLS and IV estimates are not statistically different

The return to an extra year of schooling for the cohort being considered pre democracy is $3.1 \%$. These estimates are slightly higher than the pre democracy estimates of the return to schooling in Uwaifo (2007). In Uwaifo (2007), the estimate of return to education is $2.8 \%$. Slight differences in returns are expected since the result from Uwaifo (2007) is for the whole population. Here, estimates over time for specific cohorts are derived and slight differences are possible. However, the estimates in both cases are not significantly different. Post democracy, the return to education rose substantially to $5.7 \%$. Based on these results, I find that the return to education has increased by about three percentage points 24 The estimates of return to education pre and post democracy are

\footnotetext{
${ }^{24} 2.6$ percentage point to be exact.
} 
statistically different and substantial. Given this result, the first null hypothesis is rejected. Returns to education differ between the pre and post democracy years. In addition, I cannot reject that OLS is consistent. In the next section, I explain why the difference in pre and post returns to schooling can provide evidence of the impact of democratic reform.

\section{Evidence, Estimation and Results}

The results in Table 4 and 5 show returns to education have changed when comparing 1998/1999 to $2000 / 2005$. Next, I provide empirical and descriptive evidence that democratic reform led to this change.

\subsection{Step 2: Why a Pre and Post comparison is valid for identification and the Oil boom does not explain the Change}

In this paper, a comparison of the returns to education pre and post democracy is the basis of the identification of the impact of democratic reform on returns to education. Although comparisons like this might not be useful to identify the impact of a change generally, in the Nigerian case it is possible for several reasons.

First, when comparing the two time periods, I can link all significant changes in economic indicators and factors that can affect returns to education, post 1999 to democratic reform and the significant oil boom in Nigeria post 200325 Though I provide evidence in latter sections of the paper indicating that the democratic wage reform had a significant role to play in noted changes in returns to education, I cannot attribute all the change in returns to this important reform. Meaning my identification strategy does not identify the unique impact of any particular democratic reform on returns to education. Rather, I find evidence for the impact of democratic reform generally, which includes the wage reform and other polices. Also, I refrain from saying this is the effect of democracy per se. This is because a movement to democracy in another country might not have similar effects if similar policies are not implemented. Hence, my identification strategy cannot disentangle the labor market effect of a change in institution (military to democratic) from the labor market effect, of the choice of policies implemented by the democratic government in Nigeria, some of which could be implemented by a nondemocratic government.

As mentioned above, the only change that took place in Nigeria in the comparison periods apart from democratic reforms, was the 2002 to present oil boom. One could argue that the increase in

\footnotetext{
${ }^{25}$ This conclusion is based on careful review of economic and policy accounts and papers on Nigeria between 2000 and 2005, and also reading through the documented political, economic and historical events that took place over this time period.
} 
returns to education can be attributed to the oil boom and has nothing to do with the democratic reform. This is a reasonable argument. However in the Nigerian case, one would expect that the effect of a rise in oil prices, if any, would be a level effect or an attenuated effect on returns to education. Why is this so? First, oil is a national resource, the primary beneficiary of the rise in oil prices is the Federal government and multinational corporations. Gains by multinational cooperations cannot lead to changes in returns to schooling because this sector employ an insignificant proportion of the population and repatriate profits thereby reducing the potential of indirect benefits. In addition, it is important to emphasize that substantial income benefits arising from the oil boom would only exist if the government transfers a part of this windfall into the economy via subsequent wage increases, subsidies, transfers and other general government programs. These kinds of transfers by the government should only lead to a level positive income effect with no change in returns to education. Changes in returns may only be noted with targeted transfers by the government to a particular subgroup like women or those with a particular level of education. In the Nigerian case, there is no historic evidence that both general and targeted transfers by education, post the oil boom, occurred. Up until 2006, the Nigerian government did not spend or invest the surplus income from the oil windfall but rather used this surplus income to pay of its foreign debts and grow its foreign reserve. The foreign reserve of Nigeria rose from 8 billion in 2002 to 54.8 billion dollars in 200826

Second, Uwaifo (2006) finds that the return to education dropped during past oil booms in Nigeria (1980 and 1992). The fall in returns during an oil boom is possible since benefiting from oil windfalls in Nigeria is not correlated with education but rather belonging to certain social networks connected with the governments. Moreover, these social networks prior to democracy were to a large extent independent of education. Another reason why returns to education can drop during an oil boom was expounded by Baland and Francois (2000). They provide evidence that during oil booms, individuals move into rent seeking activities because opportunities and potential benefits increase dramatically. If the ability to move to rent seeking activities reduces at higher levels of education then the returns to education may fall during a boom. In the Nigerian case, getting involved in rent seeking activities resulting from a resource boom is linked with social class, connection with government, network and not education. Therefore, when windfalls occurs in this sector, the relationship between schooling and income can be attenuated. Therefore, the effects of the

\footnotetext{
${ }^{26}$ There is anecdotal evidence that many Nigerians are complaining that the populace is not benefitting from the oil windfall and many people question the rationale of keeping so much in foreign reserve in a country with a high level of poverty and low infrastructure development. Although the Nigerian government has increased its expenditures since 1999, there is no jump in the increase in expenditure coinciding with the rise in oil prices.
} 
democratic reform on returns post 2003 might actually be higher than observed and the oil boom only serves to attenuate this effect.

A possible argument against the no positive effect of the oil boom on returns is that the oil sector tends to employ more educated people and so the boom may cause differential effects across the population resulting in an increase in returns to education. However, it is important to note that the oil sector in Nigeria is an enclave sector that employs an insignificant number of people, with few linkages in the Nigerian economy. Besides, there is no documented evidence from Nigeria that the oil sector employs a greater proportion of highly educated people, rather, the oil sector employs many low level skilled workers, few highly educated Nigerians and most of the highly skilled workers are expatriates. Furthermore, there was no substantial expansion in the sector in Nigeria over the years I am considering, despite massive increase in profitability post 2003. It is important to mention here that Nigeria belongs to OPEC which places restriction on its member in their output. The only widespread increases in income in the sector were similar to general income increases, across the private sector in the country, post the minimum wage law and wage reform in the public sector. There were no documented increases in compensation in this sector coinciding with this boom. As mention earlier, oil companies have enjoyed high profits over this period of boom but the significant oil companies in Nigeria are multinational and these companies repatriate profits rather than invest it in Nigeria, which could have created significant positive welfare effects. Off course the increased taxes paid by these companies, because of the profit increases during this period, adds to the revenue of the government. However, as highlighted earlier, this increase in revenue to the government should create only a level welfare effect if any and not an increase in the returns to education.

\subsection{Tests of the Identification Strategy}

Despite the arguments above, to quell any lingering doubts on the validity of the identification strategy, I provide results excluding 2005 and only comparing 1998, 1999 to 2000. By excluding 2005 I do not have to worry about the potential confounding effect of the oil boom from 2003 . The results in Table 6 show that returns to education increased by over 3 percentage point only a year after democracy. The swift change in returns post democracy suggests that the increase in returns was largely driven by the wage reform, initiated immediately post democracy 27 However, given that the wage reforms caused other general equilibrium effects and coincided with an expansion in the

\footnotetext{
${ }^{27}$ In Step 3 of this analysis I provide more evidence of the role of the wage reform in this changes.
} 
Table 6: Estimates of Returns to Schooling Excluding 2005

\begin{tabular}{|c|c|c|c|c|c|}
\hline \multicolumn{6}{|c|}{ Independent Variable } \\
\hline & Regime & OLS & IV FS & IV second stage & $R^{2}$ \\
\hline \multicolumn{6}{|c|}{ First Stage: Dependent Variable Year of Schooling } \\
\hline UPE & Military & NA & $\begin{array}{c}0.17^{*} \\
(0.001)\end{array}$ & & 0.36 \\
\hline UPE & Democracy (2000) & NA & $\begin{array}{c}0.13^{*} \\
(0.012) \\
\end{array}$ & & 0.35 \\
\hline \multicolumn{6}{|c|}{ Second Stage: Dependent Variable- Log Income } \\
\hline Yrs of School & Military & $\begin{array}{l}0.026^{*} \\
(0.001)\end{array}$ & & $\begin{array}{c}0.031^{*} \\
(0.001)\end{array}$ & 0.23 \\
\hline Yrs of School & Democracy (2000) & $\begin{array}{l}0.037^{*} \\
(0.001)\end{array}$ & & $\begin{array}{c}0.064^{*} \\
(0.018)\end{array}$ & 0.26 \\
\hline
\end{tabular}

Note: $* 5 \%$ significance level

demand for skilled labor, due to democracy led change in business climate and other government reforms like deregulation and privatization, I cannot make the case that the change in returns is due solely to the wage reform 28 By comparing the pre democracy years to 2000, one year after democracy, I provide evidence that the results of a change in returns post democratic reform is not linked to the confounding effect of the ongoing oil boom, which started in 2003.

Another possible argument is that the results could simply reflect a trend or a general increase in returns to education over time. To provide evidence that this is not the case, I estimate the returns to education for each year individually. 1998, 1999, 2000 are years that follow each other. If this is simply a trend, then the change in returns to education between 1998 and 1999 should be similar to the change between 1999 and 2000. Table 7 highlights the returns for the four years separately. The results provide evidence again a simple trend effect. First there is no statistically significant difference in the returns to education between 1998 and 1999, in fact the returns fell slightly. If the change in returns followed a trend, then similar to 1998 and 1999, there should be no significant change in returns between 1999 and 2000. However, there is a 3.4 percentage point increase in returns between 1999 and 2000. This increase may sound unbelievable if one was not aware of the potential immediate impacts of a wage reform. Interestingly, the returns dip between 2000 and 2005. This fall as highlighted earlier might be due to the increasing return to rent seeking activities during an oil boom. As mentioned previously, there is evidence that returns to education

\footnotetext{
${ }^{28}$ See Folawewo 2007 for an analysis of the impact of the wage increase and Okonjo-Iweala and Osafo-Kwaako, (2007) for the progress from policy reforms.
} 
drops during oil booms and the 2003 oil boom might have led to the decrease in returns from 0.064 in 2000 to 0.04 in 2005, despite continued progressive economic reforms. Oil prices in 2005 are much higher than in any other boom year and though returns have fallen from 2000 to 2005, returns in 2005 are still higher than in 1998 and 1999 when oil prices were lower. Hence, the oil boom cannot solely explain the changes in returns to schooling between 2000 and 2005 though it might have a role to play in the fall in returns between those years.

Table 7: Returns to Education by year

\begin{tabular}{|c|c|c|c|c|}
\hline & 1998 & $\begin{array}{l}1999 \\
\end{array}$ & 2000 & 2005 \\
\hline & \multicolumn{2}{|c|}{ Pre Democracy } & \multicolumn{2}{|c|}{ Post Democracy } \\
\hline \multicolumn{5}{|c|}{ First Stage: Dependent Variable- Yrs Schooling } \\
\hline & $0.15^{*}$ & $0.19^{*}$ & $0.13^{*}$ & $0.16^{*}$ \\
\hline & $(0.012)$ & $(0.014)$ & $(0.013)$ & $(0.016)$ \\
\hline \multicolumn{5}{|c|}{ Second Stage: Dependent Variable -Log I } \\
\hline \multirow[t]{2}{*}{ OLS } & $0.026^{*}$ & $0.027^{*}$ & $0.037^{*}$ & $0.045^{*}$ \\
\hline & $(0.001)$ & $(0.001)$ & $(0.001)$ & $(0.001)$ \\
\hline \multirow[t]{2}{*}{ IV } & $0.034^{*}$ & $0.030 *$ & $0.064^{*}$ & $0.040^{*}$ \\
\hline & $(0.013)$ & $(0.014)$ & $(0.018)$ & $(0.017)$ \\
\hline
\end{tabular}

Apart from the arguments stated above, another possible issue that can arise when comparing returns before and after democracy is the population being evaluated. One could argue that the change in the returns to education is not driven by democratic reform but rather by change in the population observed. To check for evidence of such a problem, first I compared descriptive statistics for the data sample across the four years noting no significant issue. I present some of these summary statistics in Table 1. In addition, all four-survey years are comparable because similar sampling methodology are used each year. However, to fully deal with change in the population argument, I follow specific cohorts pre and post democracy, those born before 1982. The choice of cohorts born before 1982 is also important because the instrument does not affect those born after this period and IV estimates could be noisy without this restriction. Also, most individuals born after 1981 are not in the workforce in the late 90s prior to democracy. However by 2005, some of those born after 1981 are in the work force. If the returns to education is estimated for the whole working population in 2005 , then it becomes more problematic to attribute pre and post differences solely to democratic reform. Such differences could be due to unique characteristics of the new entrants into the workforce. 


\subsection{Step 3: Democratic reform versus Democracy}

\section{Rationale for Testing Hypothesis 2}

The results from step two imply that oil though a potential confounding factor is not driving the resulting impact of democratic reform on returns. As a final test to provide evidence that the change in returns pre and post democracy can be linked to democratic reform, I test two hypothesis. First I test that there is no differential change in returns to education across levels of education, post democratic reform in Nigeria. Second, there is no differential change in returns to education across occupation sectors, post democratic reform in Nigeria.

Why are these tests relevant? These tests will provide evidence on whether the changes in returns to education post democracy are as a result of just a change in political system to democracy versus the choice of polices implemented by the democratic government. In addition if we find differences in the change in return to education across levels of education and occupational sectors, and the groups with higher benefits coincide with the target group of policy reforms that took place, we have indirectly showed that the changes are indeed due to reforms and not democracy per se and other confounding factors 29

It is important to emphasize again that most of the policies implemented post democracy that could have short-term impacts on returns had a direct impact on those with more education 30 In addition, the wage reform directly affected only those who work for the government, with substantial income changes for highly educated government workers. The spill-over effect of this increase for government workers, as explained in section 3.2, will lead to changes in income in the formal private sector especially those at higher levels of education. However, the change in the short-run in the formal sector will be less than those in the government sector. Hence wage workers in the private sector should see a boost in their returns but not as much as those who work for government. In contrast, those who are self employed are less likely to benefit in the short-run from the wage reform but ceteris paribus may benefit in the long run because of the general equilibrium effects.

Given the arguments above, I predict that if changes in returns to education are due to democratic reform, both null hypothesis will be rejected. Changes in returns will differ significantly across education level, occupation sector and type of employment. In particular, much higher changes in returns to education should occur for those with higher levels of education (tertiary), wage

\footnotetext{
${ }^{29}$ Notice that the wage reform and minimum wage were implemented before the oil boom. This means one cannot argue that the oil boom was used to sponsor the wage changes in the government sector.

${ }^{30}$ Specifically the wage reform, the introduction of UBE, the introduction of private universities, the deregulation of telecommunication, the change in government appointments and contracts assignments to education based criterions.
} 
workers and those working for the government while small or no changes should occur for the other comparison groups (those with less than a tertiary education, self employed, non governmental sectors).

\section{Estimation Strategy to Test these Hypotheses}

To provide evidence that the change in returns can be explained by democratic reform, First I test that there is no differential changes in returns to education across levels of education post democratic reform in Nigeria. I analyze the return to education at different levels of education by estimating the return to an extra year of schooling at each level of education using OLS on a Mincer type wage equation (see equation 3) before and after democracy. Second, I test that there is no differential change in returns to education between self employed and wage workers post democratic reform. I estimate a simple mincer equation like equation (1) for self employed and wage earners separately pre and post democracy and calculate the change if any in returns to education for each group. Third, I estimate a simple mincer equation for government workers, those who work for companies and others pre and post democracy and similar to the strategy for the earlier hypothesis, I compute the change in returns to education over these two periods if any.

$$
\log (Y)=\alpha_{2}+\gamma_{2} X+\delta_{2} X^{2}+\beta_{1} \text { yrpri }+\beta_{2} \text { yrsec }+\beta_{3} \text { yruniv }+\lambda_{2} Z+\epsilon_{1}
$$

where $\mathrm{X}$ is age, $\mathrm{Z}$ is the matrix of all relevant control variables and year dummies, yrpri is years of primary education, yrsec is years of secondary education and yruniv is years of tertiary education and $\epsilon$ is the error term.

The estimation of returns at different levels of education is identical to the estimation strategy used by Aromolaran (2004). However, in contrast to Aromolaran (2004), I use more controls in the wage equation. Moreover, while Aromolaran only looked at the pre democracy period, I estimate the returns to different levels of education pre and post democratic reform. The three hypothesis above are estimated using OLS, meaning there is a potential for a bias in the estimate of returns to education. The potential for this bias stems from the omitted variable, ability. I do not worry too much about this possibility, first, because in estimates of the average returns to education using the IV, the bias in OLS was not substantial. Second the effect of ability will be more significant in an estimation of the returns to an extra year of schooling than in the estimation of the returns to an extra year of secondary, tertiary and primary education. This is because ability is not likely to play a role in deciding the years of schooling at each levels of education in Nigeria but plays a role 
in the total years of schooling an individual attains. This is true because national and state exam tied to ability have to be taken to move between levels of education in Nigeria. Especially in the decision to move between secondary and tertiary levels of education. Given this scenario in Nigeria, I do not expect a significant ability bias in the estimate of the returns at each level of education, but we cannot rule out the possibility.

I cannot use the IV in this part of the analysis for two reasons. First, with the estimation of the returns at different levels of education, the estimation will be underidentified because their is only one instrument and three potentially endogenous variables. Second, when we break the population by sector the sample size is much smaller for government and private sector workers. This creates a lot of noise in the instrument increasing the potential of the weak instrument problem.

Despite this constraint to the estimates, given that the interest here is the comparison among education levels in changes in returns post reform, the inferences from our hypothesis should be valid whether or not estimates are biased, if bias is not time variant. There is no reason to believe that the impact of ability on the estimate of the returns to a particular level of education, if it exists, will change over time 31

\subsection{Econometric Results for Question 2}

Table 8: Returns to an Extra Year of Schooling at Different Education Levels

\begin{tabular}{cccccccc}
\hline \hline Year & \multicolumn{3}{c}{ Pre Democracy } & \multicolumn{3}{c}{ Post Democracy } & Difference \\
\cline { 2 - 7 } & $1997 / 98$ & $1998 / 99$ & pooled & 2000 & 2005 & pooled & \\
& $(1)$ & $(2)$ & $(3)$ & $(4)$ & $(5)$ & $(6)$ & $(7)$ \\
\hline Yrs of Primary & $0.019^{*}$ & $0.019^{*}$ & $0.019^{*}$ & $0.028^{*}$ & $0.032^{*}$ & $0.03^{*}$ & $0.011^{*}$ \\
& $(0.001)$ & $(0.001)$ & $(0.001)$ & $(0.001)$ & $(0.002)$ & $(0.001)$ & \\
Yrs of Secondary & $0.017^{*}$ & $0.016^{*}$ & $0.017^{*}$ & 0.001 & 0.020 & $0.014^{*}$ & -0.003 \\
& $(0.002)$ & $(0.002)$ & $(0.002)$ & $(0.003)$ & $(0.003)$ & $(0.002)$ & \\
Yrs of Tertiary & $0.095^{*}$ & $0.010^{*}$ & $0.098^{*}$ & $0.161^{*}$ & $0.177^{*}$ & $0.16^{*}$ & $0.062^{*}$ \\
& $(0.005)$ & $(0.007)$ & $(0.004)$ & $(0.007)$ & $(0.007)$ & $(0.005)$ & \\
Controls & Yes & Yes & Yes & Yes & Yes & Yes & \\
\hline \hline
\end{tabular}

Note: ${ }^{*} 5 \%$ significance level

In Table 8 the estimates of the return for an extra year of primary, secondary and tertiary education are summarized. In comparison to Aromolaran (2004) estimates, these estimates of the returns to different levels of education are lower by about 2-percentage points. This difference is

\footnotetext{
${ }^{31}$ The only possible scenario is when the standard or criteria for education advancement drops i.e., it becomes easier to pass each level or grade. There is no evidence of this in the Nigerian case for the cohort considered. However the introduction of private universities with lower entry barriers from 2000 might make time variant ability biases possible in future cohorts.
} 
primarily because he does not control for sector, or location, which are important determinants of income in Nigeria. The results show that return to an extra year of primary education is very low. Even though the returns to an extra year of primary education increased post democracy, it only increased by a percentage point. The return for an extra year of secondary education is surprisingly lower. Unlike in Aromolaran (2004), I find lower returns to secondary education than primary education. This is quite a surprise given Schultz view that the return to schooling rises with years of schooling in Africa (Schultz, 2004). Interestingly, this disturbing trend continues post democracy. With near zero returns to an extra year of secondary education in 2000 but picking up by 2005 but still lower than the returns to an extra year of primary education. On average post democracy, returns to an extra year of secondary education has increased by less than one percentage point 32

The big difference lies in the returns to tertiary education. Aromolaran (2004) also noted high returns to tertiary education. The estimates here are slightly lower than his estimates for the period he considered, 1998-1999. Table 8 shows that the return to tertiary education rose from 10\% in 1999 to about $18 \%$ point for every extra year of schooling in 2005. On average post democratic reform, returns to increased by an equivalent of about $6 \%$ points. Even though returns post democracy was statistically different from returns pre reform at the primary and tertiary level, the increase at the tertiary level is statistically and substantially different from the other two levels of education (6.2 percentage point increase to 1.1).

Based on these results, the null hypothesis is once again rejected. There are differential changes in the returns to schooling post reforms with substantial benefits solely at the tertiary level of education. Finding most of the benefits at the tertiary level of education is in consonance with our predictions given the specific reforms that took place post democracy. In addition, this finding supports the argument that the changes post democracy in returns are induced by reforms and not by oil. Notice that even if we exclude 2005, the results from testing this hypothesis still hold.

In Table 9, the estimates of the returns to education by occupational sector are summarized. In the first part of the table, I compare those who are wage workers (work for pay) to those who are selfemployed (work for profit). Notice that the change in returns to education for those who are wage workers is twice as high as the change in returns for those who are self employed. This difference still exists even if we exclude 2005 and is somewhat magnified (more than double the change for selfemployed). My finding is in consonance with the prediction that short term effects of the democratic

\footnotetext{
${ }^{32}$ It is possible that lower returns to secondary education than primary education can be supply induced. However, this is not the case in Nigeria as increase in the supply of labor post democracy was similar across both levels. Little increases in the demand for semi-skilled labor as described in the section above is a more relevant explanation.
} 
Table 9: Average Returns to Schooling by Occupation Sector

\begin{tabular}{cccccccc}
\hline \hline Year & \multicolumn{3}{c}{ Pre Democracy } & \multicolumn{3}{c}{ Post Democracy } & Difference \\
\cline { 2 - 6 } & $1997 / 98$ & $1998 / 99$ & pooled & 2000 & 2005 & pooled & \\
& $(1)$ & $(2)$ & $(3)$ & $(4)$ & $(5)$ & $(6)$ & $(7)$ \\
\hline Work for Pay & $0.031^{*}$ & $0.029^{*}$ & $0.03^{*}$ & $0.048^{*}$ & $0.051^{*}$ & $0.049^{*}$ & 0.019 \\
& $(0.0020)$ & $(0.0020)$ & $(0.0013)$ & $(0.002)$ & $(0.003)$ & $(0.001)$ & \\
Work for Profit & $0.022^{*}$ & $0.022^{*}$ & $0.022^{*}$ & $0.029^{*}$ & $0.031^{*}$ & $0.031^{*}$ & 0.009 \\
& $(0.0008)$ & $(0.0009)$ & $(0.0006)$ & $(0.001)$ & $(0.001)$ & $(0.001)$ & \\
\hline Company & $0.036^{*}$ & $0.035^{*}$ & $0.036^{*}$ & $0.052^{*}$ & $0.038^{*}$ & $0.044^{*}$ & 0.008 \\
Government & $(0.002)$ & $(0.003)$ & $(0.002)$ & $(0.003)$ & $(0.002)$ & $(0.002)$ & \\
& $0.034^{*}$ & $0.03^{*}$ & $0.033^{*}$ & $0.052^{*}$ & $0.066^{*}$ & $0.057^{*}$ & 0.024 \\
Others & $(0.002)$ & $(0.003)$ & $(0.002)$ & $(0.002)$ & $(0.003)$ & $(0.002)$ & \\
& $0.022^{*}$ & $0.022^{*}$ & $0.023^{*}$ & $0.029^{*}$ & $0.032^{*}$ & $0.031^{*}$ & 0.009 \\
Controls & $(0.0008)$ & $(0.0010)$ & $(0.001)$ & $(0.001)$ & $(0.001)$ & $(0.001)$ & \\
\hline \hline
\end{tabular}

Note: ${ }^{*} 5 \%$ significance level

reform would be felt more by those who are wage workers. This prediction makes sense given that minimum wage reform is directly relevant to wage workers. To show more specifically that a lot of the shift is truly due to this specific reform, I break down those working by type of employment. Working for a company, working for the government and others, which is primarily the self employed. While there was a 2.4 percentage point increase in returns to education for government workers, there was no significant difference in the change in returns for self-employed and those working in companies. Meaning that the increase in returns to educations for wage workers is driven primarily by increases to government workers. This finding once again highlights the importance of the wage reform whose direct beneficiaries are those who work for government. Again if we exclude 2005, the results do not change. The only difference is that the change in returns is significantly higher for company workers relative to self employed if we exclude 2005. This results suggest that returns to education seems to have decreased for company workers by 2005. This decrease could be due to several reasons including a potential attenuating effect of oil booms on returns to education. In addition the decrease could be explained by an initial response to match the changing wages in the government sector in the formal non government sector, and a decline afterwards given the abundance of skilled labor and the limit in government employment. Also, the sample of company workers contains both skilled and unskilled labor and the noted decrease in average return may be driven by an increase in the number of less educated wage workers in the 2005 sample. This scenario is highly possible given the change in the investment climate post democratic reform and the return 
of several businesses, by 2003, many of which rely on semi and unskilled workers 33 .

Could the result above lead to the conclusion that the changes in returns to education are linked only to wage reform and has nothing to do with other democratic reforms or democracy in Nigeria? The answer is no. First it took a democratic government in the Nigerian case to care enough to deal with the wage rigidities. For more than 10 years Nigeria was under military rule and there was no inclination to raise wages. I do not however deny the fact that a benevolent dictator could do the same. Nevertheless it took a democracy in Nigeria to implement it and this should be acknowledged. Also, there are changes in returns to education in the formal non-governmental sector and even among those who are self employed (about 1 percentage point increase). In addition, the noted changes in the returns in other sectors could suggest spill over effects of the wage reform or just the short-run benefits of other reforms like the general focus on education, the deregulations of key sectors, the restructuring of the banking sector and the general change in the investment climate in Nigeria. Recall from table 8 we see a an increase in returns to education for all skilled labor. This increase in return is present in all sectors. This is why though it is tempting to say these effects are purely a wage reform effect, such a conclusion could be misleading.

\section{Summary, Implication and Policy Recommendations}

\subsection{Summary}

In this paper I try to understand what can affect returns to education or cause it to be low. I review previous arguments on low returns to education and test the possible argument that reforms and change in institutions can affect returns to education, using the unique case of Nigeria. Nigeria had a drastic change in institutions from military to democracy post the sudden death of the military ruler. This change in institutions was followed by dramatics economic and labor market reforms. I ask the question did returns to education change significantly post 1999 (democracy) and can we attribute this change in returns if it exists to political and labor market reforms or does this change reflect other confounding factors that coincide with the post democracy period? I answer this question using different techniques and test three null hypotheses. First, there is no significant difference between returns to education pre and post democracy in Nigeria. Second, there is no differential change in returns to education across levels of education post democratic reform in Nigeria. Third, there is no differential change in returns to education across occupation sectors post democratic

\footnotetext{
${ }^{33}$ Recall that the results in table 8 show that substantial changes in returns are only noted for those with tertiary education. Those at the primarily and secondary level had very little changes in returns.
} 
reform.

I show despite the oil boom, that started in 2003 and can serve as a confounding factor, the results in this paper can be attributed to democratic reform. We made use of a good instrument for schooling based on the exogenous timing of the implementation of free education to estimate the average return to schooling for a specific cohort of people before democracy and post democracy. The null hypothesis that returns were the same for the two periods is rejected. The average returns to schooling increased by about 2.6 percentage points post democracy. In addition the two other null hypotheses are rejected. The change in returns post democratic reform differed across education level. Implying that low returns to schooling could be explained in part by institutions, regime and government policy choice and reforms can increase the returns to education. In addition, returns to primary and secondary levels of education are extremely low pre and post democracy. I find that changes in returns to education differed among wage workers and those who are self employed, which serves as further evidence of the thesis that the change in returns post democracy is linked with the post democratic reform. Most of the reforms implemented post democracy have shortrun benefits closely linked with those who are wage earners, work for government and have higher levels of education. Specifically, I know that the wage reform played a significant role in the change in returns to education post reform especially for the educated government worker. The results show clearly that those working for the government experienced the largest boost in their returns. However, it would be misleading to say that changes in returns to education post democracy are caused by the wage reform. Instead, short-run changes in returns to education, post democracy, can be attributed to democratic reform and a significant portion of that change can be attributed to the wage policy, which was part of these reforms.

\subsection{Implications of Results}

The results have some important implications. First, low average returns to schooling in Nigeria is more a reflection of the low return at the primary and secondary levels of education. Hence, low average returns to education in Nigeria masks heterogeneity across education levels. Take for example, Uwaifo (2007) finds average returns to education to be $2.8 \%$ in 1998-1999 which is very low. However, the returns for every extra year of tertiary education was $9.8 \%$ while the returns to an extra year of primary and secondary education was $1.9 \%$ and $1.7 \%$ respectively. Hence, low average returns to education to Nigeria can be explained in part by disparity in returns across levels.

Second, democratic reform can lead to an increase in the returns to schooling. However, the 
choice of policies by the democratic government in Nigeria has not led to equal benefits across levels of education. The primary beneficiaries of the increase post democratic reform, in terms of returns are those with tertiary education 34

Third, despite increases in the average returns to education post democratic reform, there were only marginal increases at the primary level and no increase at the secondary level. This result suggests that though reforms impact returns, other factors are necessary to be able to understand fully the low return to schooling at the secondary and primary levels.

\subsection{Recommendations \& Conclusions}

In terms of policy recommendation, first, low returns at the secondary and primary education is a significant problem that needs attention. Although military rule had a role to play in this outcome, returns have remain dismal for these levels of education post democratic reform. Part of the explanation for the lack of significant increase in returns at these level is the choice of policies post democracy that favored those with tertiary education. However, the low quality of public primary and secondary education is another possible explanation that can be investigated through government sponsored academic research. Without a clear understanding of the causes of the low returns to these levels of education, policy recommendation cannot be prescribed.

Second, with the high and increasing return to tertiary education, government should not subsidize tertiary education. Rather, more resources should be channeled to public primary and secondary levels of education. Also, the newly elected democratic government 35 needs to maintain political stability, continue economic reform, and improve security. The recent happenings with regards to religious clashes, increased armed robbery and kidnapping of oil workers in the Delta region are discouraging, and could reduce the willingness to invest in Nigeria and negatively affect returns to schooling.

In conclusion, poor governance, weak policies and bad institutions pre democracy led to labor market failures that attenuated the average returns to schooling. The exact ranking of these factors in terms of the impact on the return to education cannot be isolated in this analysis. However, a movement to democracy with wide spread democratic reform has led to a significant increase in the average returns to education. Though Nigeria experienced an oil boom coinciding in part with the democratic period, I show that the results are not driven by this potentially confounding factor.

\footnotetext{
${ }^{34}$ There is anecdotal evidence of a significant drop in immigration of highly skilled Nigerians post democracy. The increase in returns at the tertiary level to comparable levels in other countries might explain this fall.

${ }^{35}$ Nigeria began another presidential term May 2007.
} 
Hence as in Fleisher et al (2005), one can infer that the return to schooling is affected by reforms that affect the labor market in general. In addition, a low average return to schooling in Nigeria is more a reflection of the low return at the primary and secondary levels of education.

Acknowledgement This paper is based in part on my dissertation and has received funding partly from the Center for African Studies University of California, Berkeley. The author would like to especially thank Brian Wright, Ted Miguel, Alain de Janvry, Ronald Oxaca and Pat Conaway for invaluable advice. I am also grateful to participants of the DITE Workshop in Santa Barbara. Adebayo Aromolaran and Nosa Nwosu were instrumental in securing the datasets. Of course, all remaining errors are mine. Comments are appreciated. Please direct correspondence to ruth.uwaifo@econ.gatech.edu 


\section{References}

[1] Abadie, A. \& G. Imbens, (2002) "Simple and Bias-Corrected Matching Estimators for Average Treatment Effects," NBER Technical Working Papers 0283, National Bureau of Economic Research, Inc.

[2] Abadie, A. \& D. Drukker \& J. Herr \& G. Imbens, (2004) "Implementing matching estimators for average treatment effects in Stata," Stata Journal, StataCorp LP, vol. 4(3), pages 290-311.

[3] Adejumobi S. A. (1995) The Political Economy of Nigeria Under Military Rule (1984-1993) (State and Democracy Series) by (Hardcover - Jan 1995)Sapes Books.

[4] Adesina, S. (Ed.) (1982) Planning and educational development in Nigeria, Lagos, Nigeria: Board Publications.

[5] Adam S.i (2001) "The Industrial Experience of Tanzania".co-edited with Paul Lapperre Palgrave Press and his January 2005 "Development studies The Dynamics of Socio-economic Development" published by Cambridge University Press.

[6] Akokpari, John K. (1998:211-234), "The State, Refugees and Migration in Sub-Saharan Africa", International Migration (36:2).

[7] Angrist, J., (1995). "The Economic Returns to Schooling in the West Bank and Gaza Strip", American Economic Review, 85(5), 1065-87.

[8] Acemoglu, D. and J. Robinson (2000) "Why did the West extend the franchise? Democracy, inequality, and growth in historical perspective,". Quarterly Journal of Economics 115 (4): 1167-1199.

[9] Acemoglu, D. and J. Robinson (2000) "Inequality, Growth and Development Democratization or repression?" European Economic Review Volume 44, Issues 4-6 , Pages 683-693.

[10] Acemoglu, D. and J. Robinson (2001) "A Theory of Political Transitions," American Economic Review, 91, 938-963.

[11] Acemoglu, D., S. Johnson, J. Robinson and P. Yared (2004) "Institutions as the Fundamental Cause of Long-Run Growth," NBER Working Paper No. 10481.

[12] Angrist, J. and A. Krueger (1991) "Does Compulsory School Attendance Affect Schooling and Earnings?," The Quarterly Journal of Economics, MIT Press, vol. 106(4), pages 979-1014, November.

[13] Angrist, J. (1995) "The Economic Returns to Schooling in the West Bank and Gaza Strip," American Economic Review, 85(5), 1065-87.

[14] Aranki,T. (2005) "The impact of foreign workers in Isreal on the palestenian labor market" Working paper on the web www.oru.se/.../Dokument/Forskning/Nationalekonomi/.

[15] Aromolaran, A. B, (2004), "Wage returns to schooling in Nigeria" African Development review Volume 16 Issue 3 pp 433-455.

[16] Ashenfelter,O. and D. Zimmerman (1997) "Estimates Of The Returns To Schooling From Sibling Data: Fathers, Sons, And Brothers," The Review of Economics and Statistics, MIT Press, vol. 79(1), pages 1-9, February. 
[17] Baland, Jean-Marie and Patrick Francois. (2000) "Rent-seeking and resource booms." Journal of Development Economics, 2000. Vol 61: 527-542.

[18] Becker, G.S., (1964), "Human capital:a theoretical and empirical analysis with refeence to education". 2nd edn (Columbia University press New York) NBER.

[19] Bennell, P. (1996) "General versus Secondary Education in Developing Countries: a review of the rate of return evidence," Journal of Development Studies, 33,pp. 230-248.

[20] Card, D.(1995) "Earnings, schooling and ability revisted," in; Solomon Polachek,ed.,Research in labor economics, Vol.14 (JAI Press,Greenwich,CT)pp,23-48.

[21] Card, D. (2001) "Estimating the Return to Schooling: Progress on Some Persistent Econometric Problems," Econometrica, Econometric Society, vol. 69(5), pages 1127-60, September (2001)

[22] Collier, P. \& J. W. Gunning, (1999), "Explaining African Economic Performance," Journal of Economic Literature, American Economic Association, vol. 37(1), pages 64-111, March

[23] Daoud, Y., (2005). "Gender Gap in Returns to Schooling in Palestine", Economics of Education Review, 24 (6), forthcoming.

[24] Chuta, E. J. (1986) "Free Education in Nigeria: Socioeconomic Implications and Emerging Issues," Comparative Education Review 30, no 4: 523-531.

[25] Dibie, R. (2003) "Public Management and Sustainable Development in Nigeria: Militarybureaucracy Relationship," Ashgate.

[26] Federal office of statistics. (2000) "Annual abstract of statisitcs".

[27] Fafunwa, A. Babs.(1974) "History of Education in Nigeria." London: Allen and Unwin,

[28] Fleisher, B. M., Sabirianova,P. K., Wang, X., 2005. Returns to skills and the speed of reforms: evidence from Central and Eastern Europe, China, and Russia. Journal of Comparative Economics 33 (2), 351.

[29] Folawewo, A O. (2007) Macroeconomic Effects of Minimum Wage in Nigeria: A General Equilibrium Analysis. Cconference paper presentation at the Centre for the Study of African Economies (CSAE) Conference 2007 Economic Development in Africa. Retrived from the web March 2008 http://www.csae.ox.ac.uk/conferences/2007-EDiA-LaWBiDC/papers/042-Folawewo.pdf

[30] Fuente, A. \& J. F. Jimeno.(2005) "The private and fiscal returns to schooling: A general framework and some results for EU countries" CESifo Working Paper Series CESifo Working Paper No., CESifo GmbH.

[31] Gorodnichenko, Y. a, K. S. Peter (2005)Returns to schooling in Russia and Ukraine: A semiparametric approach to cross-country comparative analysis Peter Journal of Comparative Economics 33 (324-350).

[32] Glaeser,E.L. , R. La Porta, F. Lopez-de-Silanes, and A.Shleifer (June 2004)NBER "Do Institutions Cause Growth?" Working Paper No. 10568.

[33] Glewee, P. (1991) "Glewwe, Paul Schooling, Skills, and the Returns to Government Investments in Education: An Exploration Using Data from Ghana," World Bank, LSMS Working Paper No. 76, Ghana. 
[34] Glewwe, P. (1996) "The Relevance of Standard Estimates of Rates of Return to Schooling for Education Policy: A Critical Assessment.". Journal of Development Economics.

[35] Kollehlon, K. T., and Eule, E. (2003). "The Socioeconomic Attainment Patterns of African in the United States," The International Migration Review, 37, 4, 1165-1190.

[36] Lewis, P. M. and M. Bratton, "Attitudes to Democracy and Markets in Nigeria." 2000. Working Paper No 3 series Afrobarameter

[37] Linn, J. (2001) "Ten years of transition in Central Europe and the Former Soviet Union: The good news and the not-so-good news". In: Bleijer, Mario I., Skreb, Marko (Eds.), Transition: The First Decade. MIT press, Cambridge, MA, pp. 15-44.

[38] Mazonde, I.N. (1995) "Culture and Education in Development of African," http : //unpan1.un.org/intradoc/groups/public/documents/idep/unpan003347.

[39] Milanovic, B., (2002). "Does Liberte=Egalite? A Survey of the Empirical Links between Democracy and Inequality," Policy Research Working Paper Series 2875, The World Bank

[40] Mincer J, (1974), "Schooling experience and earnings" New York NBER.

[41] Minier, J. (1998), "Democracy and Growth: Alternative Approaches" Journal of economic growth Volume 3, Issue 3

[42] M. A. Mkpa (2000) "Overview of educational development:precolonial to present day" excerpts from article available on line at http ://www.onlinenigeria.com/links/eduadv.asp.

[43] Mohammed, S. (2006) "Towards Universal Primary Schooling: Estimating Returns to Education in Pakistan" Online working paper http : //www.aku.edu/ied/conference2006/abstracts/038.asp

[44] North, D. C, (1991). "Institutions," Journal of Economic Perspectives, American Economic Association, vol. 5(1), pages 97-112.

[45] Nwachukwu, A.E. (1985). "An Historical Analysis of the Roots of Universal Public Primary Education in Nigeria" (1900-1980) University of Kansas Ph. D. dissertation

[46] Nwagwu, E (December 2002) "Taming the Tiger: Civil-Military Relations Reform and the Search for Political Stability in Nigeria : Civil-Military Relations Reform and the Search for Political Stability in Nigeria" (Hardcover)

[47] Okonjo-Iweala, Ngozi. and Philip Osafo-Kwaako, (2007) Nigeria's Economic Reforms Progress and Challenges. Working Paper 6 Brookling Global Economiy and Development.

[48] Osili U. \& and B.T. Long (2008). "Does female schooling reduce fertility? Evidence from Nigeria" "Journal of Development Economics 87 (2008) 57-75. First presented as Universal Primary education and fertility: A Nigerian Experience at NEUDEC conference in 2003.

[49] Ozigi, A., \& Ocho, L. (1981). "Education in northern Nigeria". Winchester, MA:.

[50] Psacharopoulos, G., and M. Woodhall (1985) "Education for Development: An Analysis of Investment Choices," . New York: Oxford University Press.

[51] Psacharopoulos, G. (1994) "Returns to investment in education: A global update," World Development, 22(9): 1325-1343. 
[52] Psacharopoulos, G \& H.A. Patrinos, (2004). "Returns to investment in education: a further update", Education Economics, Taylor and Francis Journals, vol. 12(2), pages 111-134.

[53] Rigobon, R. \& D. Rodrik, (2004) "Rule of Law, Democracy, Openness and Income: Estimating the Interrelationships," CEPR Discussion Papers 4653, C.E.P.R. Discussion Papers.

[54] Sanda, A.O., O Ojo, and V Aveni (eds.).(1987) "The Impact of Military Rule on Nigeria's Administration". Ile-Ife, Nigeria: Faculty of Administration, University of Ife, ca.

[55] Schultz, T. P. (1988) "Educational Investments and Returns,", in H. Chenery and T.N. Srinivasan (eds.), Handbook of Development Economics, Vol. 1, Chapter 13, North Holland, Amsterdam.

[56] Schultz, P. (2004) "Evidence of Returns to Schooling in Africa from Household Surveys: Monitoring and Restructuring the Market for Education" Journal of African Econonomic .2004; 13: 95-148.

[57] Schultz, T. P. (2001) "Higher Education in Africa: Monitoring Efficiency and Improving Equity", paper presented at the Conference on International Higher Education and African Development, Yale Center for International Area Studies.

[58] Soyinka Wole (1997) "The Open Sore of a Continent: A Personal Narrative of the Nigerian Crisis" (The W.E.B. Dubois Institute Series) (Paperback)

[59] Staiger, D. and J. Stock, (1997), "Instrumental Variable Regression with Weak Instruments", Econometrica, vol. 65, pp. 557-586.

[60] Uwaifo, R.0., 2006. "Three Essays on the returns to Education Enigma in Nigeria". UC Berkeley Unpublished PhD Dissertation.

[61] Uwaifo Oyelere, R.0. (2007). "Africa's Education Enigma? The Nigerian Story" (October 2007). IZA Discussion Paper No. 3097

[62] Uwaifo Oyelere, R.O. (2008a). "Disparities in Labor Market Outcomes 11 across Geopolitical Regions in Nigeria. Fact or Fantasy?" Journal of African Development (JAD). Spring 2008.

[63] Uwaifo Oyelere, R.0. (2008b). Within and Between Gender Disparities in Income and Education Benefits from Democracy (Updated version). Older version IZA Discussion Paper No. 3221.

[64] Uwaifo Oyelere, R.0. (2008c). Economic and Econometric Evidence for and against Private Income and Employment Benefits of Education in Africa in forthcoming edited volume- Education and Change in Africa. Edited by Etim S. James.

[65] Uwaifo Oyelere, R.O (2008d). "Winners and Losers post democracy in Nigeria a look at labor market outcomes" in Tiago N. Caldeira (ed) Economics of Developing Countries (forthcoming) Nova Publishers. 